\title{
Farliga vargar och bedrägliga maskhål - Produktion av risk i mediematerial om varg och barn
}

\author{
SOFIE STRANDÉN-BACKA \\ Folkloristik, Äbo Akademi \\ sofie.stranden@abo.fi
}

\begin{abstract}
ABSTRAKT
I artikeln analyseras en diskussion om vargen och dess existensberättigande som pågick i Österbottens Tidning under år 2018 i samband med att vargar rörde sig i trakten. Utgående från Paul Slovic analyseras hur tankegångar om risk byggs upp i materialet. Syftet för artikeln är att undersöka hur varg som risk produceras och hanteras i ett tidningsmaterial, med ett särskilt fokus på de roller som barnen tilldelas. Jag intresserar mig i synnerhet för tiden, och för vad som händer med den i dessa processer. En sammansmältning av Slovics tankar om risk och Heta Lähdesmäkis och Outi Ratamäkis analys av den farliga vargen som en diskursiv resurs i det kulturella minnet i Finland ger ett underlag för en analys av ett material som $i$ sin helhet handlar om en konstruktion av risk för vargangrepp på barn. Jag föreslår termen "maskhål" som ett alternativ till det som Lähdesmäki och Ratamäki kallar för tidshopp, för att visa på den cirkulära rörelsen i den nutida ständiga återkomsten till händelser som man själv inte upplevt - dödliga vargangrepp på barn i äldre tid. Maskhålet ger tillgång till vargangreppen oberoende av tid och plats, och jag ser de känslor som berättelserna genererar som den kraft som upprätthåller existensen av maskhålet. I processen synliggörs även vad jag kallar för barnets inneboende moraliska imperativ.
\end{abstract}

NYCKELORD: varg; barn; risk; media; kulturellt minne; maskhål 


\section{Inledning}

En anledning till att studera hur ett fenomen - i det här fallet varg och barn - framställs i media är mediernas självklara och betydande del av vardagen. Liksom Göran Eriksson och Johan Östman lyfter fram påverkar medierna oss och våra uppfattningar om olika företeelser i samhället. Det vi tar del av i medierna har betydelse för hur vi relaterar till omvärlden (Eriksson och Östman 2010, 305). En förtätad diskussion om vargen och dess existensberättigande pågick i Österbottens Tidning (ÖT) under år 2018 i samband med att vargar rörde sig i trakten. Den här artikeln analyserar folkloristiskt tidningstexter om varg och barn som publicerats i den tryckta versionen av tidningen. En del av det som skrevs handlade uttryckligen om relationen varg och barn, medan andra texter tog upp andra frågor i relation till varg, exempelvis vargangrepp på tamboskap, farmrävar och hundar. I analysen av tidningsmaterialet har jag valt att anonymsiera de personer som skrivit insändare och även utelämna namnen på de personer som omnämns i tidningsartiklarna. Insändarna finns inte listade i källförteckningen. Det handlar dels om olika typ av text - ett debattinlägg skrivet av en privatperson kan inte jämställas med en journalistisk artikel, som skrivits av en utbildad journalist. Dels handlar det om att berörda personer som omtalas i artiklarna inte har möjlighet att ta ställning till min artikeltext innan publicering. Ett undantag utgörs här av två experter som av tidningen ombetts förklara varför så många är rädda för varg. Ett annat är en ledartext och en kolumn, där båda textgenrerna visserligen förmedlar enskilda personers åsikter, men i en form som kan betraktas som opinionsbildning.

Österbottens Tidning ger uttryck för en vad man kunde kalla moderat vargkritisk hållning, vilket syns i ledarskribent Kenneth Mynttis text (2018) där han argumenterar för jakt i stamvårdande syfte. Även det utrymme som getts i spalterna åt personer som ställer sig kritiska till de rådande strikta skyddsdirektiven för varg kan ses som ett ställningstagande från tidningens sida. Ett uppslag rubricerat "Vi och vargen" (Stagnäs 2018) ägnades dock åt två personer i ett försök att besvara frågan: "Varför är vi så rädda för vargen?" och för att belysa de hätska tongångarna i en samhällelig vargdebatt. Den rikssvenske vetenskapsjournalisten och författaren Henrik Ekman som studerat varg under många år, besvarade frågan med att rädslan har många orsaker, men menade att det är vargens intelligens som skrämmer mest. Filosofen Hannes Nykänen diskuterade den samhälleliga vargdebatten i allmänna ordalag, och menade att den har förlorat sin trovärdighet eftersom den ofta är osaklig och de involverade inte vill lyssna på andras argument (jfr Ehret 2020, 144). Nykänen konstaterade att debatten hettar till ännu mer om någon försöker bidra till ett sakligare diskussionsklimat. Detta uppslag 
lästes uppenbarligen av många eftersom det också kommenterades i flera insändare, och en allmän bild är att dessa insändare bekräftade Nykänens tes.

Det var många som under året skrev insändare om vargens vara eller inte vara, och en del skribenter var oroliga och väldigt upprörda eftersom vargar rört sig i närheten av skolor och daghem. Läsarinläggen kommenterar det som skrivits i tidningen, och återspeglar skribenternas inställning till det som framförs i artiklarna. Då det skrevs artiklar i tidningen framför allt under vår och senhöst som berörde varg och barn handlade också inläggen vid samma tidpunkt om detta. Det är med andra ord inte fråga om en debatt mellan läsare som framför sina olika åsikter i tidningen, vilket ofta brukar vara fallet på debattsidorna (jfr Strandén-Backa 2017; Henriksson och Häger 2017). Några vargförespråkande inlägg förekom inte. Det är upprörda, oroade, förundrade och förfärade röster som hörs i insändarna, och rösterna ger sitt bifall till aktörerna $i$ artiklarna. De jämför dagens situation med hur det var förut, vädjar till sunda förnuftet och manar till förändring. På tidningssidorna synliggörs på olika sätt människors upplevelser av risker för vargangrepp på barn.

\section{Varg, rädsla och risk}

En journalistisk artikel är tänkt att förmedla en händelse så objektivt som möjligt, och spegla händelsen ur olika synvinklar, medan insändare och andra inlägg däremot ger uttryck för en individs åsikt i en fråga, ofta med en agenda som skribenten vill föra fram (jfr Henriksson och Häger 2017, 62). Vad som här förenar de olika typerna av tidningstexter, förutom tematiken, är tankegångar om risk. Jag vill utgående från Paul Slovic (2010) analysera hur dessa tankegångar om risk byggs upp i materialet. Syftet för artikeln är att undersöka hur varg som risk produceras och hanteras i ett tidningsmaterial bestående av olika typer av texter, med ett särskilt fokus på de roller som barnen tilldelas. Jag intresserar mig i synnerhet för tiden, och för vad som händer med den i dessa processer.

Slovic har ett socialkonstruktivistiskt förhållningssätt till risk, och menar att risk är ett begrepp som vi människor har tagit i bruk för att hjälpa oss förstå och hantera fara och osäkerhet. Enligt hans synsätt är risker socialt konstruerade och beroende av ett komplext samspel av bl.a. psykologiska, sociala, kulturella och politiska faktorer. Härmed kan man inte tala om "en verklig" eller "en objektiv" risk eftersom risk alltid är beroende av någons bedömning (Slovic 2010, 733, 742, 744).

En sammansmältning av Slovics tankar om risk och Heta Lähdesmäkis och Outi Ratamäkis analys av den farliga vargen som en diskursiv resurs i det kulturella minnet 
i Finland ger ett underlag för en analys av ett material som i sin helhet handlar om en konstruktion av risk för vargangrepp på barn. Lähdesmäki och Ratamäki har anlagt ett berättelseperspektiv på finländsk varghistoria, och studerar varghistoria som en narrativ konstruktion av händelser med vargar i det förflutna. Berättelser är inte ett resultat av enskilda personers berättande utan individuella uttryck för det kulturella minnet som man har införlivats i. I korthet kan man enligt Astrid Erll förklara kulturellt minne som samspelet mellan nuet och det förflutna i socio-kulturella kontexter. Även om det är individer som minns är minnena inte enbart individuella utan alltid formade av kollektiva mönster (Erll 2008, 2, 4). Ett exempel på hur medier tidigt varit med om att forma förståelser av vad djuret varg är och gör är de rapporteringar om varg och vargattacker i rikssvenska dagstidningar från 1700- och 1800-talet som Karin Dirke analyserat. I dessa tidningar återgavs händelser från olika håll i Europa, inklusive Finland, och skapade sålunda en bild av det farliga djuret varg för de dåtida tidningsläsande svenskarna (Dirke 2015). Berättelser kan användas som diskursiva resurser som man kan hänvisa till och låna från när man själv berättar, som ett sätt att stärka den egna tolkningen och därmed också som ett sätt att övertyga andra (Taylor 2006). Berättelser skapar och upprätthåller en viss typ av kunskap, idéer som kan utgöra en del av de kulturella faktorer som Slovic talar om som en beståndsdel av risk. Lähdesmäki och Ratamäki visar till exempel genom sin studie av den performativa kraften i vargberättelser hur förståelsen för en hel djurart skapas genom berättande i den samhälleliga diskussionen (Lähdesmäki och Ratamäki 2015, 20).

Vargberättelserna för fram en likriktad, förenklad och kollektiv föreställning om den farliga vargen. Ett exempel på detta är ett vida spritt motiv som porträtterar vargars jakt på hästdragna slädar på vintern, där vargarna emanerar ur vintermörkret och framställs som glupska och rovgiriga (se Strandén-Backa 2020a). Slovic (2010, 744) hävdar visserligen att fara är något som är objektivt existerande i motsats till risk som han ser som socialt konstruerat. Han menar alltså att det existerar något som är farligt, medan riskerna för att råka ut för det farliga är socialt konstruerade på olika sätt. Men också fara kan vara socialt konstruerat: något är farligt för någon i en viss situation och under vissa omständigheter, vilket Lähdesmäki och Ratamäki visar i enlighet med Sara Ahmed (2004). Samtidigt går det också att mäta risker, också för att råka ut för ett dödligt vargangrepp. Den kalkylerbara risken för detta ligger i Finland nära noll, men som John Linnell och Julien Alleau (2016) konstaterar, står graden av rädsla för varg sällan i relation till en sådan mätbar risk för en attack.

Forskningen om varg är omfattande på både finskt och skandinaviskt håll (se t.ex. Lähdesmäki 2020; Pohja-Mykrä 2012; Bisi 2010; Ratamäki 2009; Linnell och Al- 
leau 2016; Skogen och Figari 2011). På franskt och tyskt språkområde har vargen studerats särskilt med avseende på dess allt större utbredning i Alperna och de konsekvenser detta har för landsbygdsbefolkningen (se t.ex. Heyer och Hose 2020; Masius och Sprenger 2015; Bobbé 2006; Breitenmoser 1998). I Finland har Heta Lähdesmäki (2020) kulturhistoriskt analyserat varg och de föreställningar om varg som uppkommit, använts och utmanats. Sanna Ojalammi och Nicholas Blomley har (2015) studerat varg ur ett kulturgeografiskt perspektiv med fokus på spänningen mellan skyddet av varg och känsla av säkerhet. Juha Hiedanpää, Jani Pellikka och Sanna Ojalammi (2016) tangerar mitt intresseområde då de undersöker den upplevda betydelsen av vargens närvaro och utövad vargpolicy i vargområden i sydvästra Finland. De använder sig av material som består av inlägg av vargmotståndare, särskilt föräldrar som ger uttryck för sin oro för sina barns säkerhet och sina förväntningar på myndighetsingripande.

Med tanke på hur vargen framställs i västerländsk tradition är det viktigt att påminna om att den här artikeln handlar om föreställningar om vargen. Ändå kan texten på grund av sitt fokus på möten mellan varg och barn reproducera stereotypa bilder av vargen, även om ett mål med min artikel är att dekonstruera uttrycken för rädsla för varg. Mitt tillvägagångssätt för att göra detta är en kulturanalytisk närläsning (se t.ex. Nilsson och Marander-Eklund 2018) av mediematerialet med fokus på risk. Med hjälp av kulturanalys kan man blottlägga dolda strukturer i det till synes enkla och självklara. I sin artikel "The psychology of risk" (2010) vill Paul Slovic visa att risk är ett komplext fenomen, och centralt är att "risk" betyder olika saker för olika människor. När experter talar om risk menar de ofta sannolikhet för skada eller dödsfall, medan allmänheten har en betydligt bredare uppfattning om vad risk innebär. Allmänhetens uppfattning omfattar kvalitativa beståndsdelar som exempelvis osäkerhet, rädsla, katastrofpotential, kontrollerbarhet och rättvisa. Slovic menar att många konflikter om risk kan vara ett resultat av att experter och lekmän har så olika definitioner av begreppet. Han konstaterar att det inte är särskilt förvånande att upprepning av riskstatistik sällan har önskad effekt när det gäller att förändra folks attityder (jfr Ehret 2020). En förståelse av risk som något socialt konstruerat och därmed som något som byggs upp av olika faktorer, ökar möjligheterna till bättre riskbedömningar och beslut, menar han. Det handlar med andra ord om att ta hänsyn till olika uppfattningar av risk och till de många beståndsdelar som risk byggs upp av om man ska kunna öka acceptansen av de åtgärder som föreslås och förankra besluten hos allmänheten. Slovics studier visar att lekmän tenderar att tillskriva det man är rädd för högre risker, och det är mycket som kan påverka ens uppfattningar. Bland annat omfattande mediebevakning kan bidra till ett förhöjt intryck av risk. Media har, enligt Slovic, en tendens att rapportera om negativa aspekter 
eller avvikelser från det "normala" (Slovic 2010, 743). Den upplevda risken ökas genom rapporteringen. Att varg observerats i bostadsområden och i närheten av skolor på den förhållandevis tättbefolkade österbottniska landsbygden bedöms av tidningen som viktigt att bevaka, och vargens beteende väcker uppmärksamhet i vargdiskussionen. Vargen upplevs helt enkelt komma för nära människor.

\section{Den onormala vargen}

Under långa tider har man inte observerat varg i de bebyggda områdena i kusttrakterna i Österbotten. Vargen som art har, enligt en vitt spridd tanke om rumslig fördelning, placerats längst bort från människan, i ödemarken. Men vargen bryr sig inte om en sådan mänsklig indelning, utan gör besök över de imaginära gränser som människan konstruerat (Bobbé 2006, 120). Eftersom människor placerat vargar (och andra stora rovdjur) i vildmarken (se Lähdesmäki 2020, 149f) - ofta genom intensiv jakt närmare bosättningarna (se t.ex. Mech 1995) - händer det något med de vargar som söker sig till bebyggda områden och bort från omgivningar som betraktas som naturliga för vargen. Också när människors förväntningar om vargarnas beteende inte sammanfaller med beteendet som vargar uppvisar vid ett möte mellan djur och människa händer något. Vargarnas "onaturliga oräddhet" har lett till en diskussion om den risk som orädda vargar kan utgöra för människor (von Arx et al. 2020, 124). Vargar som kommer alltför nära människan och inte anses vara tillräckligt skygga, börjar också uppfattas som "inte riktiga vargar", som "onaturliga" djur med ett "onaturligt beteende" (Figari och Skogen 2011, 12) det vill säga som så kallade "varghybrider" eller som "problemvargar". Lähdesmäki och Ratamäki analyserar konstruktionen av fenomenet "problemvarg" (fi. häirikkösusi), och visar att termen blev allmän i vargdiskussionen efter att ordet "skadedjur" försvann ur lagtexten år 1993. Lähdesmäki och Ratamäki poängterar att användningen av begreppet problemvarg definierar vargar som kommer nära människor som onormala. De visar dock på det relativa i en sådan definition, eftersom man förut inte ansett vargar som rört sig bland människoboningar som onormala. Folk var visserligen rädda för vargar och förargade över den skada de kunde ställa till med, men man var ändå van vid kontakten med dessa djur. Efter hand som antalet vargar minskade rörde sig självfallet färre vargar i närheten av människor. I takt med detta började man betrakta beteendet hos vargindivider som närmade sig människor som något som vittnade om vargindividens onormala natur. Och med ett beteende som anses avvikande för vargar kan man motivera avlivning (Lähdesmäki och Ratamäki 2015, 27-30; Lähdesmäki 2020, 162f; jfr Ojalammi och Blomley 2015, 57). 
På flera håll i svenska Österbotten har man under 2018 observerat varg i närheten av skolor och daghem, och Österbottens Tidning rapporterade under året om hur man hanterat situationen. Det handlar om akuta åtgärder som att eleverna i en skola dirigerades direkt in i skolbyggnaden efter att en varg setts utanför skolan på morgonen, att eleverna inte fick gå ut under den första rasten, och att flera vuxna än vanligt var ute tillsammans med barnen. Föräldrarna till barnen i en skola meddelades via skolans informationskanal och via personliga textmeddelanden om att en varg hade setts röra sig vid skolan och skolan uppmanade också föräldrarna att inte släppa ut sina barn ensamma i skymning och gryning då vargar brukar vara som mest aktiva. I skolorna funderade man över hur vargens närvaro skulle komma att påverka undervisningen, om man skulle kunna fortsätta vistas i skogen på skolgymnastik och biologilektioner (Lillkvist 2018a; Eriksson 2018a). Vid daghemmet i Oravais centrum uppgavs personalen ständigt vara beredd att slå larm, och hade en beredskapsplan om vargen skulle synas till. Personalen hade en klocka som de skulle ringa i och ropa "Alla in!", men utan att använda ordet "varg" för att inte skrämma barnen. Man övervägde att förkorta eftermiddagens utevistelse eftersom det då bara fanns en i personalen på plats. "Man vet ju inte när vargen dyker upp", inflikade rektorn för skolan (Lillkvist 2018b). Tanken om den plötsligt uppdykande vargen som finns i det kulturella minnet går igen här (Strandén-Backa 2020b), liksom att vargens blotta närvaro upplevs som hotfull (se Ojalammi 2015). Man agerar utgående från rädslan för vad som skulle kunna hända om varg och barn kom i direkt kontakt med varandra, och genom sitt välmenande handlande förstärker man föreställningen om den farliga vargen.

I sitt brev från riksdagen rubricerat "Vargen kommer alltför nära!" (2018) redogör Anna-Maja Henriksson, justitieminister och ordförande för Svenska folkpartiet, för hur hon och hennes parti agerat i vargfrågan. Hon menar att alla nu måste förhålla sig till en situation som är annorlunda än för bara några årtionden sedan då man inte behövde oroa sig för att träffa på en varg i skogen. Då, i hennes barndom, existerade vargen främst i sagan om Rödluvan (se Dundes 1989), en saga som lär ut att vargen är farlig. Hon menar att man idag får finna sig i att det finns vargar i landet och att detta rovdjur hör till de skyddade djurarterna. Ändå, menar Henriksson, ska man inte behöva vara rädd för vargangrepp på människor, och hon omnämner särskilt äldre och barn. Hon betonar vikten av att myndigheterna och beslutsfattarna tar befolkningens oro på allvar för att återställa tilltron till myndigheterna. "Vi ska inte behöva vänta på att någon enda mänska blir vargens offer!", skriver ministern. Av Henrikssons inlägg kan man utläsa att vargen faktiskt är något att oroa sig över, att man måste ta oron på allvar och att något måste göras som inte redan blivit gjort. Den enligt Slovic $(2010,742)$ 
så viktiga tilliten till myndigheterna och deras beslut har förlorats, nu när livet ter sig så annorlunda eftersom vargen finns i nära anslutning till människor och för att den inte längre får jagas fritt. Vargen fridlystes i Finland 1973, och mycket av det som debatteras härrör från olika åsikter om artens status som utrotningshotad.

De vargar som observerats på gårdsplaner, runt skolor och daghem definieras som problemvargar, och i de insändare som publicerats i Österbottens Tidning konstrueras de som avvikande, farliga och som sådana vargindivider som borde avlivas. En skribent undrar hur en del kan vara "så säkra på att den varg som kommer intill husknuten inte är en störd individ som ger sig på allt och alla?" (ÖT 10.4.2018). Vargen ska skygga för människan, annat beteende anses vara onaturligt. Vargarna som har setts i bebyggelsen anses vara "utan naturlig respekt för människan" (ÖT 7.4.2018). Att skjuta varg som söker sig in på bebyggda områden "är den enda lösningen" som medför att vargarna återfår sin "naturliga skygghet" och i fortsättningen ska "undvika kontakt med människor" (ÖT 3.10.2018). Det är alltså människan som ska se till att vargen återfår ett beteende som bedöms som naturligt för arten. Vargens närvaro "för nära" människan konstrueras som något hotfullt och som därmed utgör en risk för angrepp på barn. I det följande diskuterar jag hur tankar om risk för vargangrepp byggs upp genom den diskursiva resursen om den farliga vargen.

\section{Tänk om vargen kommer}

Lähdesmäki och Ratamäki har konstaterat att man ofta lyfter fram vargangreppen under 1800-talet, särskilt de väldokumenterade attackerna på 1880-talet i Åboregionen när man berättar om varg i dag. Samtidigt är de en viktig byggsten i föreställningen om den farliga vargen (Lähdesmäki och Ratamäki 2015, 24). Varghändelserna som refereras till här handlar om en serie predationsangrepp på barn av ett vargpar som förde bort barnen, dödade dem och åt upp kropparna. Det exakta antalet döda är svårt att säkerställa, men siffran 22 anges ofta (Linnell och Bjerke 2003, 30-31). Efter en analys av material som kretsade kring dessa (Strandén-Backa 2020b), kunde jag konstatera att berättelserna om möten mellan barn och varg i förfluten tid kännetecknas av vargar som framställs som blodtörstiga, grymma och människoätande, medan barnen representeras som oskyldiga offer och de vuxna som maktlösa (jfr Lähdesmäki och Ratamäki 2015, 24f). Samtidigt finns det underliggande tankegångar, både medvetna och omedvetna, som kopplas ihop med vargfrågan. Ett exempel är när Zacharias Topelius i sin vilja att uppamma kämpaglöden mot vargarna under den tid då angreppen pågick producerar vargen som en gemensam fiende, till och med som en landsfiende 
(se Strandén-Backa 2020b). Rädslan för rovdjur som vargar kan manipuleras för att uppnå strävanden av olika slag (jfr Linnell och Alleau 2016). Användning av en händelse från det förflutna "för att forma bestämda meningsskapande och handlingsorienterade helheter" har Peter Aronsson gjort till en grunddefinition för begreppet historiebruk (Aronsson 2004, 18). Historiebruk handlar om urval av historiekulturen - allt som refererar till det förflutna - och formar ett historiemedvetande, det vill säga hur man föreställer sig att något har varit. Detta i sin tur inverkar på hur man upplever samtiden och skapar förväntningar om vad som kommer att hända i framtiden (Aronsson 2004, 17-18).

I det tidningsmaterial från 2018 som handlar om varg och barn hänvisar man visserligen inte direkt till vargangreppen på 1800-talet på särskilt många ställen, men det förflutna och föreställningar om händelserna i slutet av 1800-talet ger ändå genklang i några av inläggen. En debattskribent hänvisar kort till händelserna under 1800-talet, en annan skriver mera uttryckligt att "på 1800-talet dödades flera barn av vargar" (ÖT 18.10.2018), men båda hänvisar till det kulturella minnet om händelser med barndödande vargar. Sådana vargberättelser organiserar människors erfarenheter och känslor i förhållande till varg och skapar tolkningar om relationen mellan människa och varg såväl i nutiden som i det förflutna. Genom berättandet blir egnas och andras erfarenheter till de nutida läsarnas eller åhörarnas erfarenheter (Peterson och Langellier 2006). Endast en kort hänsyftning till händelserna räcker för att aktivera eller påminna om föreställningen om den farliga vargen. Enligt Lähdesmäki och Ratamäki blir samtidens erfarenheter del av det kulturella minnet av det finländska förflutna och läsarna och åhörarna delar erfarenheter från upplevelser i det förflutna som de själva inte har upplevt (Lähdesmäki och Ratamäki 2015, 19-21) i och med att föreställningar om händelserna har skapats. Ur detta föds rädsla för att vargar ska angripa barn också i dag.

En av insändarskribenterna alluderar visserligen inte på Åbohändelserna i sin framställning, men hon har helt införlivat tanken om att vargar dödar barn och att de när som helst kan komma att göra det igen. "Kalla det intuition eller vanligt sunt bondförnuft, men nästa blir ett barn som får sätta livet till. Vi vet det alla och vi är livrädda för att det ska hända" (ÖT 18.4.2018). Hon skriver att hon har slagit på varningsljusen och jobbar på att samla underskrifter till ett medborgarinitiativ om rätten att skjuta varg. Det som alla "vet", är att vargar dödar barn - de har gjort det förut och de kan eller kommer att göra det igen, och denna föreställning används för att åstadkomma en förändring i skyddsdirektiven.

I debattinläggen påtalas upprepade gånger oron som föräldrarna känner och den rädsla barnen själva upplever vid blotta tanken på vargens närvaro (jfr Figari och 
Skogen 2011, 10; Ojalammi 2015, 11). Föräldrar vågar inte lämna sina småbarn att sova utomhus i barnvagnen, de lite större barnen får inte leka ensamma ute eller gå ut när det är mörkt. Att barnen inte längre får gå eller cykla till skolan utan vuxen kan te sig underligt och kräva sin förklaring. Eller att man har specialutrustning med sig att ta till vid en eventuell vargattack:

\begin{abstract}
Jag har en flicka på nio år som är så rädd att hon inte vågar gå från stället där hon släpps av med taxin efter skolan till huset där hon bor. Det handlar om lite på över en 200 meter lång sträcka. Hon vågar inte heller leka eller vistas ute ensam, vilket hon annars alltid tagit som en självklarhet. Visserligen finns det andra hus på vägen när hon ska gå hem ensam, men också mycket skog. Hon har spray i fickan och en visselpipa och en tuta i väskan. Ska det vara så? (ÖT 18.4.2018)
\end{abstract}

Det är svårt att förklara för barnen varför deras handlingsutrymme begränsas utan att samtidigt skrämma upp dem. För denna skribent framträder vargen som "skogens haj" som enligt henne "dödar bara för att döda" (ÖT 18.4.2018). Genom denna överföring av föreställningar om den kallt beräknande robotliknande mördarmaskinen, som hajen framställs som (Midgley 1996, 23) på vargen frammanar skribenten det som Mary Midgley $(1996,19)$ kallar för "the folk figure of the wolf", en sinnebild för skoningslös grymhet. Det verkar vara denna varg som både skribenten och hennes dotter är rädda för. Upplevelsen av risk och känslan av hot är mycket större till följd av det kulturella minnet av barndödande vargar och den diskursiva resursen om den farliga vargen som florerar och uttrycks på olika sätt i ord och handling. Det här sätter saker i rörelse, som har direkta följder för den vanliga människan och för den vanliga vargen.

En konkret åtgärd som några kommuner vidtagit för att dämpa oron är att ordna skolskjuts från och till hemdörren för alla barn som bedömts vara i behov av detta under kortare eller längre perioder (jfr Ojalammi 2015, 11-12). Att det kan vara svårt att navigera i malströmmen av risktankegångar märks exempelvis i Pedersöre, där man har konsulterat en viltexpert för att kunna fatta ett beslut "som varken är överdrivet eller negligerar situationen" (Björklund 2018). Detta fenomen noteras också i Schweiz då det gäller myndigheters kommunikation om varg: hur ska man balansera fakta om situationen där inget har hänt, direktiv om hur man ska hantera ett vargangrepp och agera så att inget sådant händer som inte får hända (von Arx et al. 2020, 132). Det är svårt att bedöma risken för vargangrepp på barn. Tidningen publicerade också artiklar som handlar om föräldrar som oroar sig över barnens skolväg, för inte alla som vill får extrainsatta skolskjutsar (jfr Hiedanpää et al. 2016, 12-13). De som inte beviljats extra 
skolskjuts - vargtaxi - berättar om hur de ordnar med egen skjuts eller vuxen följeslagare åt sina barn också för så korta sträckor som några hundra meter. En pappa säger att han inte vill riskera att hans barn "blir de första som blir uppätna av varg i Finland i modern tid" - en indirekt allusion på händelser i det förflutna. En annan säger att de delvis ångrar sitt beslut att bosätta sig på landsbygden på grund av det upplevda varghotet. En tredje manar till åtgärder eftersom: "Vi har många barn här i Oravais, men inte ett enda för mycket" (Lillkvist 2018a, 2018b, 2018c). Den diskursiva resursen om den farliga vargen är i aktiv användning.

\section{Tankehopp och maskhål}

I ledartexten "Myndigheterna ska agera vid fara" (2018) argumenterar Kenneth Myntti för licensjakt i stamvårdande syfte och möjlighet för gårdsägare till skyddsjakt. Han anför flera exempel på den i hans tycke ohållbara och verklighetsfrämmande situationen där varg dagligen observeras i tättbebyggda områden, vilket bland annat lett till extrainsatta skolskjutsar så "att skolbarnen ska komma till skolan utan att på vägen bli angripna av vargar". Myntti gör här ett svindlande hopp från åsynen av en varg till angrepp av den, och han förstärker sin argumentation för vargrisken genom sin användning av pluralis - det handlar inte om bara en varg, utan om flera, och alla dessa är funtade så att de angriper barn. På ledarplats skapar han alltså vargar som angriper barn av de vargar som man endast har observerat. Enligt Ahmed (2004, 7-8) formas ens förståelse av något utgående från tidigare berättelser som man kanske inte ens är medveten om, men som ändå påverkar och som gör att man uppfattar något som farligt. Ahmed menar att rädslan inte är ett resultat av att något skulle vara farligt, i det här fallet vargen, utan för att det är någon som upplever den som farlig. När vi tänker på vad som skulle kunna hända om vi träffar på en varg har vi redan ett intryck av riskerna vid ett sådant möte, och dessa tankegångar är formade av berättelser i det kulturella minnet om andra människors kontakt med andra vargar.

Händelserna i äldre tid är alltså en del av formeringen av föreställningar om vargar i dag även om det bara är en del individer som är införstådda i händelserna, och ännu färre som återberättar dem. Denna sammansmältning av händelser i det förflutna med föreställningar om vad som skulle kunna hända också idag benämns av Lähdesmäki och Ratamäki som ett "tidshopp". Tidshoppet är möjligt eftersom berättelserna om vargangreppen i äldre tid sällan kontextualiserar vargens verksamhet och ger den en förklaring utgående från rådande materiella och sociala omständigheter. Berättelserna framställer inte vargen som en beståndsdel i ett sammanhang, skriver de, utan lösgör 
den från sin kontext vilket ger den en statisk och oföränderlig karaktär. Denna avsaknad av sammanhang leder till att bilden som förmedlas fixerar föreställningen om vad vargar är och hur de beter sig, och gör den allmänt gällande för alla vargar i alla tider och på alla platser. Händelserna på 1800-talet blir ett bevis för den farliga vargen både förr och nu. Händelserna konkretiseras i nutiden i tal och skrift, men är inte manifesterade som faktiska och fysiska händelser i dag - inget barn har blivit angripet, dödat och uppätet i nutid i Finland. Men föreställningarna om händelserna lever i berättelserna och fastän det gått 140 år sedan händelserna är de fortfarande en viktig del av det kulturella minnet om vargen (Lähdesmäki och Ratamäki 2015, 24-26). Blotta omnämnandet av barn och varg i samma sammanhang aktiverar föreställningar om händelser i förfluten tid, oberoende av om det handlar om Åbohändelserna på 1880-talet, andra belagda händelser eller föreställda händelser.

Genom detta tidshopp använder man beskrivningar av händelser i det förflutna för att förklara nutida situationer (Lähdesmäki och Ratamäki 2015, 39). I sin tolkning av tidshoppet som Lähdesmäki och Ratamäki för fram är det framför allt återkomsten till händelser som man inte själv upplevt som jag vill uppehålla mig vid. Det de kallar för tidshopp skulle jag vilja benämna för något annat, eftersom termen tidshopp för tankarna till en linjär tid (jfr Davies 1987), där tiden har en början, fortgår och kanske har ett slut. Jag tycker mig se en återvändande rörelse i detta, där tiden i stället blir cirkulär. För ett fenomen som detta vill jag föreslå termen "maskhål", ursprungligen från Albert Einsteins och Nathan Rosens relativitetsteori. Maskhål beskrivs enligt Nationalencyklopedin som "ett nära samband mellan två, normalt sett, rumsligt och/eller tidsmässigt, vitt skilda händelser i universum" (NE [online]). Genom ett sådant tunnelaktigt maskhål kan man färdas oberoende av tid och rum och uppleva det som redan hänt då det händer - en sådan tanke används med förtjusning inom science fiction. Termen maskhål kan användas i överförd bemärkelse för det fenomen som Lähdesmäki och Ratamäki uppmärksammar. Maskhålet handlar i det här fallet om den starka rädsla för att vargar i dag ska angripa och döda barn, kanske till och med äta av deras kroppar. Hela diskussionen som förs på tidningssidorna handlar om denna rädsla, som är så stark, att den för en del har omvandlats till visshet om att detta kommer att inträffa. Maskhål kräver mycket energi för att kunna existera, och detta gäller även för de maskhål som jag vill uppmärksamma och som får sin kraft genom berättande. Berättelserna växer sig starkare genom upprepning (Herman och Mitchell 2013) - innehållet börjar uppfattas som sant ju flera gånger man hör samma berättelse. Och genom att berättelser kopplas till känslotillstånd stärks både innehållet och intensiteten av känslorna som berättelsen förmedlar (Ahmed 2004), och jag ser de känslor som berättelserna genererar som den 
kraft som upprätthåller existensen av maskhålet.

Något som de analyserade exemplen tidigare i artikeln visar är att det sker olika slag av överföringar som förstärker upplevelsen av risk, fara och hot. Utöver det sistnämnda maskhålet där tiden blir relativ och händelserna från 1800-talet överförs till nutid, förekommer det psykologiska tankehoppet med en inbyggd överföringsmekanism där en observation på ett ögonblick blir till ett fullbordat faktum med uppförstorat resultat. Den tredje överföringen som jag noterat är den där en djurarts egenskaper liknas vid en annan djurarts egenskaper så att föreställningar om den ena djurarten fäster vid den andra så att två arters föreställda egenskaper och karaktär smälter samman. Genom denna överföring av negativa egenskaper skapas en monstruös varelse, värd att fruktas och som måste bekämpas med alla medel som står till buds, något jag vill åskådliggöra genom ett studium av ett fall i Oravais där rektorn för skolan agerar mot vargens närvaro.

\section{Ur led är tiden}

En artikel i september (Nygård 2018) beskriver att varg upprepade gånger har observerats runt skolbarackerna i Oravais centrum. I artikeln berättar rektorn att han är mycket kritisk mot polisen som inte vill avliva vargen. Rektorn upplever att han inte längre kan garantera elevernas säkerhet, och han anser att det är polisen som ska skydda barnen från vargar. I artikeln intervjuas kommunikationschefen för polisinrättningen som säger att det är lagen som styr polisens befogenheter. Polisen har enligt lagen rätt att avliva ett djur bara om det beter sig aggressivt och orsakar fara för människors liv eller hälsa. Han poängterar att det inte räcker med "en allmän rädsla" för vargar. Att ett djur rör sig $i$ bebyggelsen anses inte utgöra en fara för någon, och polisen har inte fog för att fatta ett avlivningsbeslut (jfr Ojala och Blomley 2015; Hiedanpää et al. 2016).

Ungefär två veckor senare återkommer Oravaisvargen i en artikel där rektorn försöker få bukt med den på byråkratiska vägar. Han har läst barnskyddslagen vars syfte är att säkra barns rätt till en trygg uppväxtmiljö, och med detta som grund tänker han göra en barnskyddsanmälan av Viltvårdscentralen, för att pröva om barnskyddslagen är starkare än viltvårdslagen. Från Regionförvaltningsverket meddelar man dock att detta inte är möjligt, eftersom lagen är till för trygghet i hemmet (Eriksson 2018b). Anmälan riktas mot Viltvårdscentralen eftersom rektorn anser att det är denna instans som ska handskas med de problem som vargstammen upplevs förorsaka. Han motiverar sin plan: "Egentligen är det vargen som är ett hot, men det är staten som äger vargen och det är viltvårdscentralen som har hand om rovdjuren". Upplevelsen av situa- 
tionen som uppstått med en varg som rör sig i närheten av skolor och daghem och som varken man själv, traktens jägare eller polisen får avliva ter sig som en förvrängning av ett tänkt idealtillstånd där människan positioneras över vargen.

Som nuläget är upplever rektorn "frustration och maktlöshet över att myndigheterna gömmer sig bakom dålig lagstiftning", och de svar som myndigheterna har gett förändrar ingenting. Han exemplifierar med de råd som han fått av polis och viltvårdscentralen för vad ett barn ska göra om han eller hon möter en varg. Polisen anser att man ska ringa nödcentralen, men rektorn tycker det är orimligt att en sjuåring ska ha telefon med sig och klara av att ringa 112. Råden från viltvårdscentralen som rektorn fått, och som han har skickat till föräldrarna lyder: "ta sig bort från vargen, göra sig så stor som möjligt och om vargen biter sig fast ska man sticka fingrarna i dess ögon". Rektorn tycker att det är föräldrarna som ska avgöra om de vill ge sina barn sådana anvisningar: "Man kan fråga sig om det här föder mera trauma än vad det skapar trygghet. Ett grymt råd åt barn i dagens Finland" (Eriksson 2018b).

Innehållet i artiklarna för fram ett tydligt budskap om den farliga vargen, som med all sannolikhet kommer att angripa människors barn. Insändarskribenterna diskuterar det som stått i tidningen. Råden man fått från myndigheterna signalerar fara - en fara som ska hanteras på ett liknande sätt som våldtäktsmannen i buskarna: skrika, göra motstånd, sikta på ögonen. De konkreta instruktioner som getts angående hur man ska bete sig om en varg attackerar upplevs av en av skribenterna som märkliga. Han anser att det är konstigt att man inte får skjuta de vargar som rör sig i bebyggda områden. Han använder ord som "skymfar" och "förnedrar" när han beskriver hur han upplever att "vi österbottningar" behandlats av personer som han uppfattar förringar den rädsla som han menar många lever med. Skribenten sympatiserar med rektorn som på olika sätt försöker skydda eleverna, och tycker att rektorns argument är goda (ÖT 18.10.2018). En skribent upprörs över det han läst om att dagispersonal "i dagens Finland" ska slå larm med en klocka om vargen kommer och han tycker detta tillvägagångssätt är något alldeles ofattbart (ÖT 7.4.2018). Tiden är ur led och världen, så som skribenterna hittills upplevt den, tycks ha vänts upp och ner.

\section{Barnets inneboende moraliska imperativ}

En reaktion på artikeln sticker ur från de andra. Det är fråga om ett inlägg i brevform av en elvaårig pojke som skrivit med hjälp av sin mamma (ÖT 24.10.2018), ett brev som han också ska skicka till Finlands president "för min rektor har sagt att han lyssnar på barn". Det är omöjligt att veta vem som tagit initiativ till insändaren, men pronome- 
nanvändningen gör att man som läsare uppfattar texten som pojkens. Samtidigt är det många beståndsdelar i texten som gör att jag ganska tydligt upplever en vuxens röst. I texten uttrycker man exempelvis sitt stöd för skolans rektor som barnskyddsanmält Viltvårdscentralen och riktar ett tack till honom. I brevet vänder sig pojken direkt till polisen och i rubriken - kanske satt av tidningen - ställs frågan "Varför får vi inte hjälp av polisen?" till dem. I brevtexten skriver pojken att det har varit mycket problem med vargar, och att minst en har slagit sig ner i centrum av Oravais. Han tecknar en snabb bakgrund där han delger läsaren att vargen har setts många gånger, också i närheten av familjens hus. Han skriver med förvånad indignation: "Ändå kom polisen inte och sköt den" trots att vargen observerats i ett bostadsområde mitt på dagen. Han undrar varför inte polisen skyddar "oss", något som han trodde var polisens jobb att göra. Han frågar sig om det inte är tillräckligt att vargen dödat både husdjur och farmrävar, och avslutar stycket med frågan: "Ska vi låta den döda ett barn också?"

Det är ett långt brev presidenten ska få. Det fortsätter med en jämförelse mellan varg och människa, först med en tankelek om hur polisen skulle ha agerat om det varit en människa "med ett dödligt vapen" som "smög omkring i vår kommun" dag och natt. Skribenten tänker sig att polisen hade fört bort personen, och inte bara "sjasat iväg den en bit" - en släng av sleven mot fördrivningsförsöken som upplevs som tafatta byråkratiska halvmesyrer. Pojken fortsätter sin jämförelse mellan varg och människa, men nu är det han själv som ställs i relation till vargen: "Vargen har starka käkar och vassa tänder som kan döda till och med en stor älg. Jag har inte det." Han berättar att han har tillverkat ett vapen att försvara sig med ifall vargen kommer in på gården. Han fortsätter beskriva situationen där vuxna känner sig otrygga och har börjat bära vapen, där hans lillebror inte vågar släppa in katten utan att först kolla i fönstret om den har vargen efter sig. Barnen tillåts inte leka ensamma på gården och i skolan vågar man inte skida eller orientera på grund av vargen. De råd som barnen har fått tycker pojken är märkliga: "Av polisen och Viltcentralen har vi fått rådet att bära överfallslarm för att skrämma vargen och att sticka våra fingrar i vargens ögon och kämpa hårt emot om den biter oss." Han undrar om det är så vi ska ha det i Finland, att "vargar skyddas mer än barn". Den opersonliga framställningen i uppmaningen från myndigheten blir genom pojkens omskrivning med pronomenet vi till en mycket kroppslig realitet när det är "våra fingrar" som ska stickas i vargens ögon om den biter "oss". Det är tydligen många barn som väntas bli angripna av vargen, och det är mycket som verkar vara fel i tillvaron som pojken beskriver.

Den upp- och nervända situationen där barn förväntas bli anfallna av varg i stället för att jägare ska beviljas tillstånd att skjuta varg måste förändras, menar man i in- 
sändarna som ständigt pekar på nya och - som man tycker - alltmer absurda lösningar. Att avliva vargen konstrueras som den självklara lösningen på all denna galenskap. Det som här uppfattas som det enda rätta är att människor och vargar hålls åtskilda från varandra, och att de vargar som överträder människornas gränser ska avlivas. Dessa gränser är baserade dels på föreställningar om vargens rätta plats och på den farliga vargen, föreställningar som byggs upp och upprätthålls i den offentliga diskussionen, där media är en viktig aktör (jfr Lähdesmäki och Ratamäki 2015, 25). Världsåskådningar kolliderar, och i debatten tar man till det ultimata argumentet som alla måste bevekas av, nämligen det oskuldsfulla barnet som riskerar att dödas av den farliga vargen. I den moderna västvärlden har barnet belagts med ett, vad man kunde kalla, inneboende moraliskt imperativ. På så sätt kan man använda företeelsen barn i en strävan att uppnå olika slags syften (jfr Kvaerndokk 2020). När inga andra argument biter på motståndarna låter man barnet upplåta sin ljusa stämma. Liknande tillvägagångssätt - om än mer genomarbetade och konstnärliga - finner man exempelvis i fosterländsk diktning, nykterhetsrörelsens visor eller i söndagsskolornas frälsningssträvanden (jfr Strand 2016). Den vuxne skribenten placerar sitt budskap i barnets mun och låter barnet tala i jagform i dikten eller sången i syfte att vädja till läsarnas eller åhörarnas bättre sida och vägleda dem på den rätta vägen. Även om insändaren är undertecknad med pojkens namn med tillägget "med hjälp av mamma" ser man en vuxens närvaro i texten och en tydlig agenda: den farliga vargen måste bort. Föräldrarna är rädda för att något ska hända deras barn, och vill skydda dem från de faror som upplevs som överhängande. Resonemanget lyder att det bara är en fråga om tid innan ett barn blir attackerat av vargen. Att varg har anfallit och dödat barn är något som en skribent (ÖT 18.4.2018) uttrycker som något som "vi" vet och genom detta vetande förpliktas "vi" till ett ansvar att se till att det inte händer igen. Partiordförande Anna-Maja Henriksson använder genomgående detta pronomen i sitt brev från riksdagen. Detta återkommande "vi" är det kollektiv som är insatt i den diskursiva resursen om den farliga vargen, och alla läsare av Österbottens Tidning erbjuds en plats i detta kollektiv.

\section{Vargens tid, vargens plats}

Man kan fråga sig vem som är motparten i debatten - storstadsbor som inte förstår hur det är att bo på landet, vetenskapare och lagstiftare som också hänförs till storstäder, myndigheter och den överstatliga konstruktionen Europeiska Unionen. Det är i vilket fall som helst ofta ett anonymt kollektiv, som befinner sig geografiskt på en annan plats än skribenterna, aktörerna i artiklarna och även redaktörerna för tidningen. Dessa 
osynligt närvarande meningsmotståndare försöker hindra "oss" att leva ett liv fritt från rädsla för vargangrepp. Samtidigt måste också dessa krafter övertygas eftersom det är de som förmår återställa ordningen på laglig väg. Urs Breitenmoser menar att landsbygdsbefolkningens förhållning till rovdjur är en radikalt annan än den urbaniserade majoritetens. Enligt honom har stadsbefolkningen en mer romantiserad bild av rovdjur och natur, vilket bidrar till att de stora rovdjuren blir vad han kallar för "känslomässiga nyckelarter" (Breitenmoser 1998, 279). De blir med andra ord symboler för något. För några står vargen kanske för den otämjda naturen, orörd av människohand, kanske något slags rå urkraft, medan den för andra innebär konflikter av olika slag (se t.ex. Pohja-Mykrä 2014; Ratamäki 2009).

Kombinationen av rädsla och förnekelse av vargangrepp på människa är explosiv inom grupper som förenas i sitt motstånd eller förespråkande av varg, och synliggör de större sociala och politiska konflikter som vargar blivit symbol för (Linnell och Alleau $2016,365)$. Slovic $(2010,743)$ poängterar att gemene man ingalunda är irrationell eller okunnig, utan påverkas liksom expertisen av emotioner i ett komplext system av ideologier, värderingar och sätt att se på världen. Konflikterna som förknippas med varg hör mera ihop med konflikter mellan olika grupper av människor än vargens direkta påverkan på människan (Redpath et al. 2013). Det rör sig om konflikter mellan stad och land, olika livsstilar och värderingar, och om olika kunskapssystem - så kallat sunt förnuft eller vetenskap (jfr Skogen et al. 2013). Det spelar egentligen ingen större roll vad vetenskap och statistik säger om hur ovanligt det är att människor angrips och dödas av varg i Finland. Värdekonflikter och en allting genomsyrande misstro på myndigheters och beslutsfattares riskhantering kan inte minskas genom tekniska analyser. Och, menar Slovic, att försöka lösa riskkonflikter med hjälp av mera vetenskap och statistik kommer sannolikt bara att förvärra konflikten (Slovic 2010, 744).

Debattinläggen speglar ett missnöje med hur myndigheterna hanterar vargsituationen och röster höjs om krav på förändring. Ett av inläggen är skrivet av en österbottnisk representant för Svenska folkpartiet och i det framgår att partiets lokalavdelning anser att det är regeringens uppgift att se till att det finns ett "regelverk som ger oss trygghet och möjlighet att leva och verka i alla delar av Finland" (ÖT 7.4.2018). En av skribenterna skriver att "vi på landet förgäves har försökt få myndigheterna att förstå - - att vargen ska vara rädd för människan, inte tvärtom!" (ÖT 9.10.2018). Resonemanget liknar det som Hiedanpää et al. $(2016,8)$ beskriver där vargkritiker hävdar att vargen har inkräktat på människornas rättigheter så att det numera är människor som ska undvika vargar och att det är vargarna som har lagen på sin sida. I inläggen kan man spåra en risk för anarki. Om inte "berörda myndigheter agerar resolut och 
kraftfullt i den situation som nu råder med vargar som rör sig i tätt bebyggda områden och kring husdjursbesättningar" och använder sina befogenheter finns det en risk för att "allmänheten förlorar sitt sista förtroende för hur det offentliga hanterar situationen" (ÖT 3.10.2018) och underförstått tar saken i egna händer (se von Essen 2016, 23, 236ff). Missnöjet i ett inlägg riktas inte bara mot myndigheternas förmenta undfallenhet, utan allmänheten beskylls också för att ha "fått ett tålamod och en fördragsamhet med myndighetsbeslut som inte är av denna världen". Skribenten menar att det vore viktigt att allmänhetens rättsuppfattning skulle gå i linje med politikers och myndigheters beslut, så att man kan känna delaktighet och lojalitet mot samhället (ÖT 18.10.2018). Egentligen föreslår debattskribenten den lösning som Slovic $(2010,745)$ också förespråkar, nämligen att involvera dem som besluten påverkar och dem som är intresserade av frågorna i både riskbedömnings- och beslutsprocessen för fortsatta åtgärder.

Sammanfattningsvis kan man konstatera att när de tre huvudtrådarna risk, föreställningar om den farliga vargen, och barn knyts samman uppstår ett fascinerande tillstånd som jag kallar för maskhål. Denna lånade term gör det möjligt att visa hur berättande om något skapar ett kraftfält där tid och plats upphör att existera. Det komplexa fenomenet risk genererar ytterligare kraft till maskhålet där vi är i direkt kontakt med de händelser som utspelade sig i en annan tid. Den diskursiva resursen om den farliga vargen lånar beståndsdelar från händelser i nutid, där vargar angripit boskap, farmrävar och sällskapsdjur, och förstärker den nutida människans farhågor om att något ska hända också människor, i synnerhet barn. Berättelser om föreställningar av olika slag sugs in i maskhålet och ger det vidare styrka, som till exempel när någon drar förhastade slutsatser utgående från åsynen av varg. Man gör en barnätande monstervarg av den varg som enbart observerats. Det är mycket som är fel med den tid som vi lever $i$, anser man i insändarna, när vargen upplevs åtnjuta ett större skydd är barnen. Något måste göras åt denna upp- och nervända tillvaro, och man förvånas och förfäras över att myndigheterna inte inser detta. Att det finns ett bedrägligt maskhål som producerar en viss typ av kunskap om vargen och får nutida människor att uppleva 1880-talets människors skräck och att agera utgående från denna känsla är en mekanism som verkar i det fördolda.

Artikeln är skriven inom projektet "Varggränser. Affektiva möten mellan människan och det vilda" som finansieras av Svenska litteratursällskapet $i$ Finland. 


\section{Källor}

\section{TIDNINGAR}

Anon. Österbottens tidning 7.4.2018; 10.4.2018; 18.4.2018; 3.10.2018; 9.10.2018; 18.10.2018; 24.10.2018.

Björklund, Jenny. 2018. "Lövöbarn skjutsas på grund av vargoro. Barn i Lövö får skjuts till skolan på grund av varg." Österbottens tidning 16.5.2018.

Eriksson, Heidi. 2018a. "Elever hölls inne på grund av vargen." Österbottens tidning 11.4.2018.

Eriksson, Heidi. 2018b. "Oravaisvargar blir fall för barnskyddet/Gör barnskyddsanmälan på grund av vargarna." Österbottens tidning 10.10.2018.

Henriksson, Anna-Maja. 2018. "Vargen kommer alltför nära!" Österbottens tidning 4.3.2018.

Lillkvist, Marcus. 2018a. "Vargrisken vardag för skogsarbetaren/Har mött tre vargar, bär yxan i stöveln." Österbottens tidning 28.1.2018.

Lillkvist, Marcus. 2018b. "Klockan varnar för vargen." Österbottens tidning 5.4.2018.

Lillkvist, Marcus. 2018c. "Nekades utökad skolskjuts." Österbottens tidning 23.9.2018.

Myntti, Kenneth. 2019. "Myndigheterna ska agera vid fara." Österbottens tidning 7.4.2018.

Nygård, Sofia. 2018: "Varg stryker omkring skola i Oravais." Österbottens tidning 29.9.2018.

Stagnäs, Mayvor. 2018: "Vi och vargen. Biologen: Vargen skrämmer med sin intelligens. Filosofen: Debatten om vargen osaklig." Österbottens tidning 7.10.2018.

\section{ARTIKLAR}

Ahmed, Sara. 2004. The cultural politics of emotion. London \& New York: Routledge.

Aronsson, Peter. 2004. Historiebruk. Att använda det förflutna. Lund: Studentlitteratur.

Arx, Manuela von, Ilona Imoberdorf och Urs Breitenmoser. 2020. "How to communicate wolf? Communication between the authorities and the population when wolves appear." I Encounters with wolves. Dynamics and future, redigerad av Marlis Heyer och Susanne Hose, 123-136. Budyšin: Serbski Institut.

Bisi, Jukka. 2010. Suomalaisen susikonfliktin anatomia. Uleåborg: Uleåborgs universitet. http://jultika.oulu.fi/files/isbn9789514261473.pdf 
Bobbé, Sophie. 2006. "From the zoning project to T. measures. The divergent conceptions of the territorial management of wolves in the Alpine Arc." Journal of alpine research, 4: 119-128. https://www.persee.fr/doc/rga_0035-1121_2006_ num_94_4_5597

Breitenmoser, Urs. 1998. "Large predators in the Alps. The fall and rise of man's competitors." Biological Conservation, 83, no. 3: 279-289. https://doi.org/10.1016/ S0006-3207(97)00084-0

Davies, Karen. 1987. "Manlig tid och kvinnors verklighet." Tidskrift för genusvetenskap. 4: $26-41$.

Dirke, Karin. 2015. "Where is the big bad wolf? Notes and narratives on wolves in Swedish newspapers during the eighteen and nineteen centuries." I A fairytale in question. Historical interactions between humans and wolves, redigerad av Patrick Masius och Jana Sprenger, 101-118. Cambridge: The White Horse Press.

Dundes, Alan. 1989. Little Red Ridinghood. A casebook. Madison: The University of Wisconsin Press.

Ehret, Sebastian. 2020. "Understanding the return of wolves. An educational scheme for discussing a multidimensional phenomenon." I Encounters with wolves. Dynamics and future, redigerad av Marlis Heyer och Susanne Hose, 137-155. Budyšin: Serbski Institut.

Eriksson, Göran och Johan Östman. 2010. "Receptionsanalys." I Metoder i kommunikationsvetenskap, redigerad av Mats Ekström och Larsåke Larsson, 305-330. Lund: Studentlitteratur.

Erll, Astrid. 2008. "Cultural memory studies. An introduction." I Cultural memory studies. An international and interdisciplinary handbook, redigerad av Astrid Erll och Ansgar Nüring, 1-15. Berlin: De Gruyter.

Essen, Erica von. 2016. In the gap between legality and legitimacy. Illegal hunting in Sweden as a crime of dissent. Uppsala: Sveriges lantbruksuniversitet.

Fagerlund, Rainer, Kurt Jern och Nils Erik Villstrand. 2001. Finlands historia 2. Helsingfors: Schildts.

Figari, Helene och Ketil Skogen. 2011. "Social representations of the wolf." Acta Sociologica, 54, no. 4: 317-332. https://doi.org/10.1177/0001699311422090

Gillis, Herlitz och Per Peterson. 2011. Vargen. Kramdjur eller hatobjekt. Malmö: Liber.

Henriksson, Blanka och Andreas Häger. 2017. "Tidningsdebatt om hot mot den finlandssvenska minoriteten." I Föreställda finlandssvenskheter. Intersektionella perspektiv på det svenska i Finland, redigerad av Sven-Erik Klinkmann, Blanka Henriksson och Andreas Häger, 57-83. Helsingfors: Svenska litteratursällskapet. 
Hermann, Pernille och Stephen Mitchell. 2013. "Constructing the past. Introductory remarks." Scandinavian Studies, 85, no. 3: 261-266. DOI: 10.1353/scd.2013.0031

Heyer, Marlis och Susanne Hose, redaktörer. 2020. Encounters with wolves. Dynamics and future. Budyšin: Serbski Institut.

Hiedanpää, Juha, Jani Pellikka och Sanna Ojalammi. 2016. "Meet the parents. Normative emotions in Finnish wolf politics." TRACE: Finnish Journal for Human-Animal Studies, 2: 4-27. https://trace.journal.fi/article/view/53412

Kverndokk, Kyrre. 2020. "Talking about your generation. 'Our Children' as a trope in climate change discourse." Ethnologia Europaea, 50, no. 1: 145-158. doi: https:// doi.org/10.16995/ee.974

Linnell, John och Julien Alleau. 2016. "Predators that kill humans. Myth, reality, context and the politics of wolf attacks on people." I Problematic wildlife. A cross-disciplinary approach, redigerad av Francesco Angelici, 357-371. Cham: Springer.

Linnell, John och Tore Bjerke. 2003. Rädslan för vargen. En tvärvetenskaplig utredning. Viltskadecenter \& NINA/NIKU. Stiftelsen för naturforskning og kulturminne. https://www.viltskadecenter.se/pdfs/Radslan_for_vargen.pdf

Lähdesmäki, Heta. 2020. Susien paikat. Ihminen ja susi 1900-luvun Suomessa. Jyväskylä: Jyväskylä universitet.

Lähdesmäki, Heta och Outi Ratamäki. 2015. "Kykenemmekö luopumaan susifetissistä? Kriittinen luenta suomalaisesta susihistoriasta." I Suden kanssa, redigerad av Juha Hiedanpää och Outi Ratamäki, 16-41. Rovaniemi: Lapplands universitetspress. http://urn.fi/URN:ISBN:978-952-310-981-0

Masius, Patrick och Jana Sprenger, redaktörer. 2015. A fairytale in question. Historical interactions between humans and wolves. Cambridge: The White Horse Press.

Mech, David. 1995. "The challenge and opportunity of recovering wolf populations." Conservation Biology, (april): 270-278. https://www.jstor.org/stable/2386772

Midgley, Mary. 1996. Beast and man. The roots of human nature. London \& New York: Routledge.

NE [online]. Nationalenycklopedin, uppslagsordet "maskhål". https://www.ne.se/ uppslagsverk/encyklopedi/lång/maskhål

Nie, Martin. 2003. Beyond wolves. The politics of wolf recovery and management. Minneapolis: University of Minnesota Press.

Nilsson, Fredrik och Lena Marander-Eklund. 2018. "Under ytan. Kulturanalyser av det bortglömda, dolda och triviala." Budkavlen, 97: 1-10.

Ojalammi, Sanna. 2015: "Susi, tunteet, ja tila." Maaseudun uusi aika, 1: 5-18. http:// www.mua-lehti.fi/arkisto/1_15/ojalammi.pdf 
Ojalammi, Sanna och Nicholas Blomley. 2015. "Dancing with wolves. Making legal territory in a more-than-human world." Geoforum, 62 (juni): 51-60. https://doi. org/10.1016/j.geoforum.2015.03.022

Peterson, Eric och Kristin Langellier. 2006. "The performance turn in narrative studies." Narrative Inquiry, 16, no. 1: 173-180. https://doi.org/10.1075/ ni.16.1.22pet

Pohja-Mykrä, Mari. 2014: Vahinkoeläinsodasta psykologiseen omistajuuteen. Petokonfliktien historiallinen tausta ja nykypäivän hallinta. Åbo: Åbo universitet. http:// urn.fi/URN:ISBN:978-952-10-8515-4

Ratamäki, Outi. 2009. Yhteiskunnallinen kestävyys ja hallinta suomalaisessa susipolitiikassa. Joensuu: Joensuu universitet. http://urn.fi/URN:ISBN:978-952-219-232-5

Redpath, Stephen et al. 2013. "Understanding and managing conservation conflicts." Trends in Ecology \& Evolution, 28, no. 2: 102-109. https://doi.org/10.1016/j. tree.2012.08.021

Skogen, Ketil och Olve Krange. 2003. "A Wolf at the Gate. The anti carnivore alliance and the symbolic construction of community." Sociologica Ruralis, 43, no. 3: 309325. https://doi.org/10.1111/1467-9523.00247

Skogen, Ketil, Olve Krange och Helene Figari. 2013. Ulvekonflikter. En sociologisk studie. Oslo: Akademika.

Slovic, Paul. 2010. "The psychology of risk." Saúde Soc, 19, no. 4: 731-747. https:// doi.org/10.1590/S0104-12902010000400002

Strand, Karin. 2016. Brott, tiggeri och brännvinets fördärv. Studier i socialt orienterade visor i skillingtryck. Möklinta: Gidlunds.

Strandén-Backa, Sofie. 2020a. "Förföljd av vargar. Vargens mytiska funktion i framställningar av vargöverfall." Svenska landsmål och svenskt folkliv, 142: 121-140.

Strandén-Backa, Sofie. 2020b. "'Bara en fot och en känga'. Vargdödade barn i Finland i folktradition och mediematerial." Budkavlen, 99: 63-89. https://journal.fi/ budkavlen/article/view/99531/57189

Taylor, Stephanie. 2006: "Narrative as construction and discursive resource." Narrative Inquiry, 16, no. 1: 94-102. DOI: 10.1075/ni.16.1.13tay 